\title{
APLIKASI REAL-TIME MONITORING KEHADIRAN KARYAWAN TERINTEGRASI DENGAN FINGERPRINT SYSTEM PADA UNIVERSITAS DEHASEN BENGKULU
}

\author{
Hari Aspriyono ${ }^{1}$, Riska $^{2}$ \\ 1hari.aspriyono@gmail.com, ${ }^{2}$ riska.iskandar@unived.ac.id \\ 1,2Universitas Dehasen Bengkulu
}

\begin{abstract}
Abstrak
Fingerprint semakin luas digunakan di berbagai bidang sebagai perangkat untuk identifikasi kehadiran karyawan di sebuah kantor, perusahaan, sekolah, universitas dan lain sebagainya. Di Universitas Dehasen Bengkulu Fingerprint System telah diimplementasikan namun belum dapat memenuhi kebutuhan luaran yang diinginkan oleh bagian kepegawaian. Dalam penelitian ini, peneliti akan membangun aplikasi real-time monitorning kehadiran karyawan yang terintegrasi dengan fingerprint system sehingga kehadiran karyawan dapat dimonitor secara langsung. Dari penelitian ini dihasilkan sebuah aplikasi real-time monitoring kehadiran karyawan pada Universitas Dehasen Bengkulu dengan hasil pengujian bahwa secara umum aplikasi dapat berjalan baik dengan yang diharapkan, sedangkan dari hasil pengujian kecepatan sinkronisasi data dari mesin fingerprint ke aplikasi akan berjalan baik (cepat) jika data yang ada pada mesin fingerprint adalah data terbaru maksimal 1 bulan terakhir, untuk itu perlu adanya backup data yang telah lebih dari 1 bulan pada mesin fingerprint.
\end{abstract}

Kata kunci: real-time, monitoring, kehadiran, karyawan, fingerprint system

\section{Abstract}

Fingerprint is increasingly used in various fields as a device for identifying employee attendance in an office, company, school, university and so on. At Universitas Dehasen University Bengkulu the Fingerprint System has been implemented but has not been able to meet the external needs desired by the staffing department. In this study, researchers will build monitorning real-time employee attendance applications that are integrated with the fingerprint system so that employee attendance can be monitored directly. From this study produced a real-time application monitoring employee attendance at Universitas DehasenBengkulu with the results of testing that in general the application can run well as expected, whereas from the results of testing the speed of data synchronization from the fingerprint engine to the application will run well (fast) if the data the fingerprint engine is the latest data for a maximum of 1 month, for that it is necessary to backup data that has been more than 1 month on a fingerprint machine.

Keywords: real-time, monitoring, attendance, employee, fingerprint system

\section{Pendahuluan}

Perkembangan teknologi fingerprint semakin luas digunakan di berbagai bidang. Seperti halnya penggunaan fingerprint sebagai perangkat untuk identifikasi kehadiran karyawan di sebuah kantor, perusahaan, sekolah, universitas dan lain sebagainya. Namun demikian tidak semua kebutuhan luaran yang diinginkan dapat diperoleh dengan fingerprint system yang tersedia. Di Universitas Dehasen Bengkulu telah mengimplementasikan fingerprint system untuk presensi kehadiran karyawan, namun output yang dihasilkan belum sesuai dengan apa yang diharapkan yakni bagian kepegawaian belum dapat melihat daftar kehadiran karyawannya secara real-time setiap harinya.Dari sistem yang ada saat ini, laporan kehadiran karyawan dicetak per bulan dengan cara melakukan backup database yang ada di fingerprint system. Hal ini tentu memiliki kelemahan yang harus diperbaiki dengan menciptakan sistem yang baru. Aplikasi real-time monitoring dapat dibangun dengan memanfaatkan bahasa pemrograman PHP yang berbasis opensource, untuk meminimalisir biaya namun tetap memenuhi kebutuhan sesuai yang diharapkan. Presensi karyawan dapat dipantau secara real-time setiap harinya malalui layar monitor yang dipasang di ruangan bagian kepegawaian. Selain itu kehadiran karyawan juga dapat ditampilkan melalui laman web yang dapat diakses dari internal universitas. Berdasarkan uraian di atas, peneliti mengajukan judul penelitian "Aplikasi Real-time Monitoring Kehadiran Karyawan Terintegrasi dengan Fingerprint System pada Universitas Dehasen Bengkulu". Adapun tujuan dari penelitian ini adalah dengan adanya aplikasi Real-time Monitoring kehadiran karyawan terintegrasi dengan Fingerprint System pada Universitas Dehasen Bengkulu diharapkan dapat memberikan 
kemudahan untuk mendapatkan informasi kehadiran karyawan dan secara tidak langsung dapat meningkatkan kedisiplinan karyawan, karena merasa kehadirannya dimonitor setiap harinya.

Sedangkan manfaat dari penelitian ini adalah sebagai berikut:

a. Menciptakan aplikasi real-time monitoring kehadiran karyawan dengan biaya yang relatif murah karena menggunakan software opensource.

b. Memberikan informasi kehadiran karyawan kepada bagian kepegawaian setiap hari tanpa harus menunggu rekap absensi bulanan.

Informasi adalah kumpulan dari beberapa fakta yang terorganisasi dan telah diproses agar memiliki nilai tambah selain nilai-nilai individual. Nilai dari informasi tersebut diantaranya bagaimana membantu pembuat keputusan mencapai tujuan organisasi mereka. Dapat membantu orang dalam organisasi melakukan tugas-tugas dengan efisien dan efektif. Aplikasi atau disebut dengan Perangkat lunak aplikasi (bahasa Inggris: software application) adalah suatu subkelas perangkat lunak komputer yang memanfaatkan kemampuan komputer langsung untuk melakukan suatu tugas yang diinginkan pengguna. Biasanya dibandingkan dengan perangkat lunak sistem yang mengintegrasikan berbagai kemampuan komputer, tapi tidak secara langsung menerapkan kemampuan tersebut untuk mengerjakan suatu tugas yang menguntungkan pengguna[1].

Mekanisme Fingerprint dalam absensi merupakan sebuah sistem yang ada di suatu instansi yang digunakan untuk mencatat daftar kehadiran setiap anggota instansi tersebut. Sistem absensi mencatat identitas anggota instansi dan waktu keluar-masuk anggotanya. Sistem absensi juga mempunyai kemampuan untuk memberikan laporan yang akurat[2]. Hypertext Preprocessor atau lebih singkatnya PHP adalah bahasa skrip yang dapat ditanamkan atau disisipkan ke dalam HTML. Dengan PHP kita dapat membuat website menjadi dinamis. PHP banyak digunakan oleh para programmer website. PHP dapat digunakan untuk membangun sebuah CMS (Content Management System)[3].

Database didefinisikan sebagai kumpulan data yang teintegrasi dan diatur sedemikian rupa sehingga data tersebut dapat dimanipulasi, diambil dan dicari secara cepat. Selain berisi data, database juga berisi metadata. Metadata adalah data yang menjelaskan tentang struktur dari data itu sendiri. Sebagai contoh, anda dapat memperoleh informasi tentang nama-nama kolom dan tipe data yang ada pada sebuah tabel. Data nama kolom dan tipe yang ditampilkan tersebut disebut metadata[4]. Database berbeda dengan Database Management System (DBMS). DBMS adalah kumpulan program yang digunakan untuk mendefinisikan, mengatur, dan memproses database; sedangkan database itu sendiri esensinya adalah sebuah struktur yang dibangun untuk keperluan penyimpanan data. DBMS merupakan alat atau tool yang berperan untuk membangun struktur tersebut[4]. ERD adalah sebuah model data yang menggunakan beberapa notasi untuk menggambarkan data dalam hal entitas dan relasi yang digambarkan oleh data tersebut[5].

\section{Metode}

Tahap awal dari penelitian ini adalah menentukan arsitektur sistem real-time monitoring kehadiran karyawan. Arsitektur sistem terlihat pada gambar berikut ini:

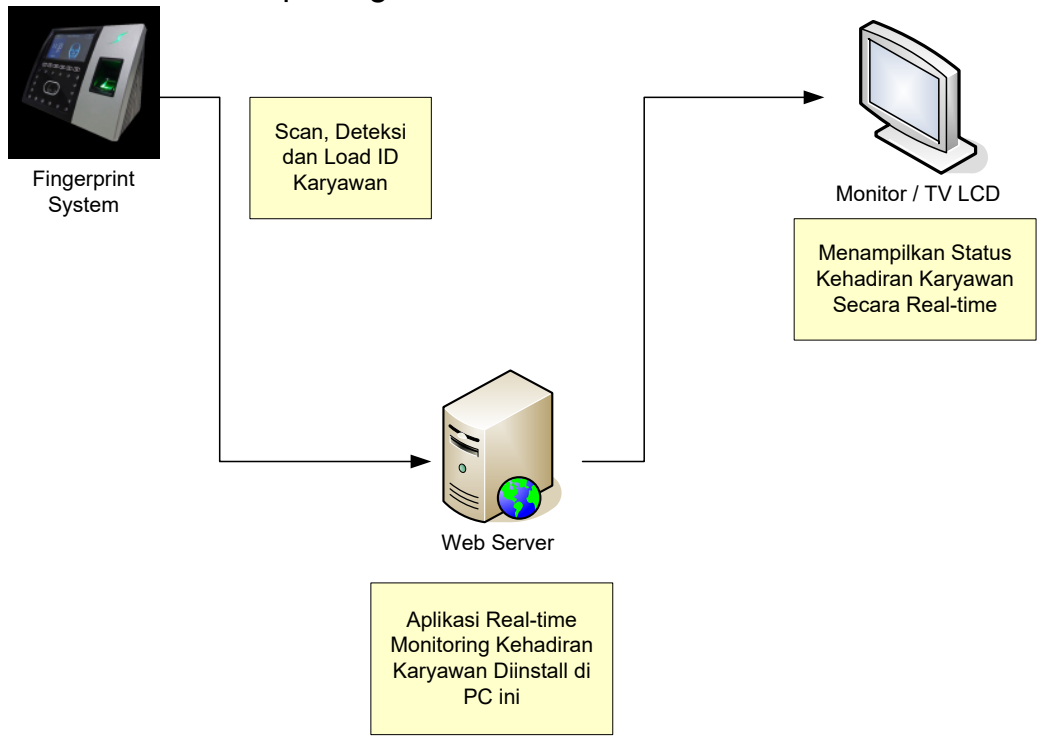

Gambar 1. Arsitektur Sistem Real-time Monitoring Kehadiran Karyawan 
Dari gambar di atas dapat diuraikan bahwa, aplikasi real-time monitoring kehadiran karyawan terhubungdengan fingerprint system yang telah terpasang di Universitas Dehasen Bengkulu. Dalam aplikasi terdapat database yang terkait dengan database yang ada pada fingerprint system. Aplikasi yang akan dibuat dapat menerima respon dari fingerprint system secara langsung sehingga informasi yang dihasilkan dari aplikasi dapat ditampilkan pada layar monitor atau TV LCD.

Dari arsitektur yang telah didesain, selanjutnya dimodelkan sistem kedalam diagram konteks seperti terlihat pada gambar berikut ini:

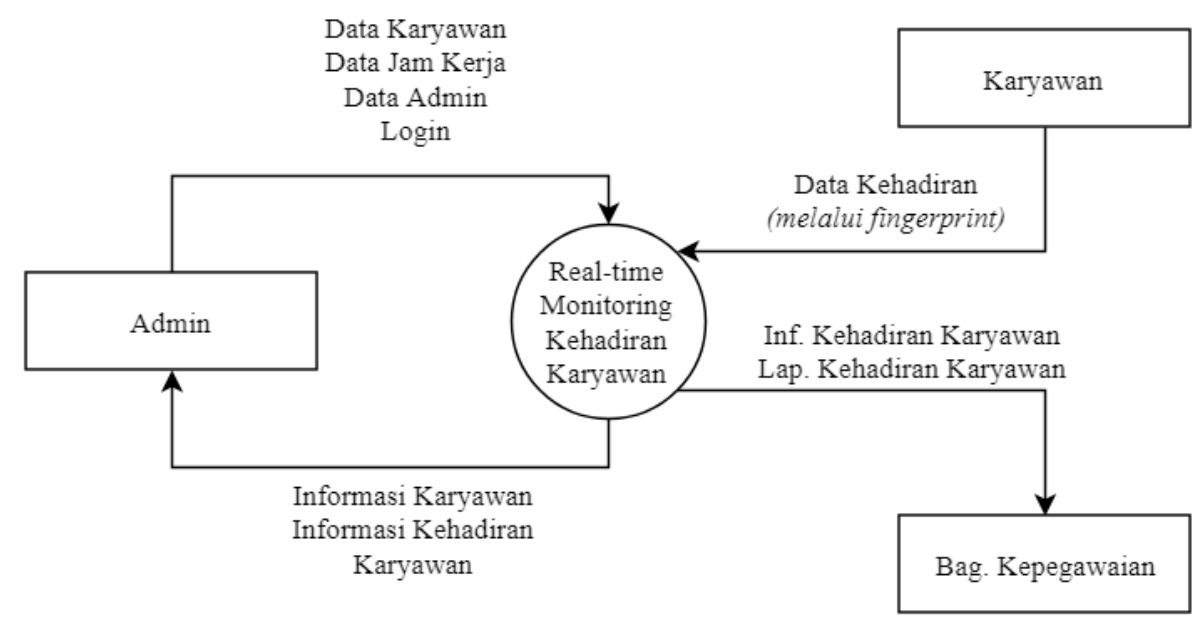

Gambar 2. Diagram Konteks

Dari diagram konteks di atas, pada sistem real-time monitoring kehadiran karyawan ini terdapat 3 entitas luar yaitu admin, bagian kepagawaian dan karyawan. Admin sebagai pengguna tertinggi memasukkan data karyawan, data jam kerja, data admin dan login. Bagian Kepegawaian dapat melihat informasi kehadiran karyawan secara real-time. Sedangkan karyawan setiap harinya melaukan checkin sebagai tanda kehadirannya. Semua data dikelola dalam sistem real-time monitoring kehadiran karyawan.

Dari diagram konteks tersebut kemudian dikembangan menjadi model data yang digambakan dalam bentuk relasi tabel.

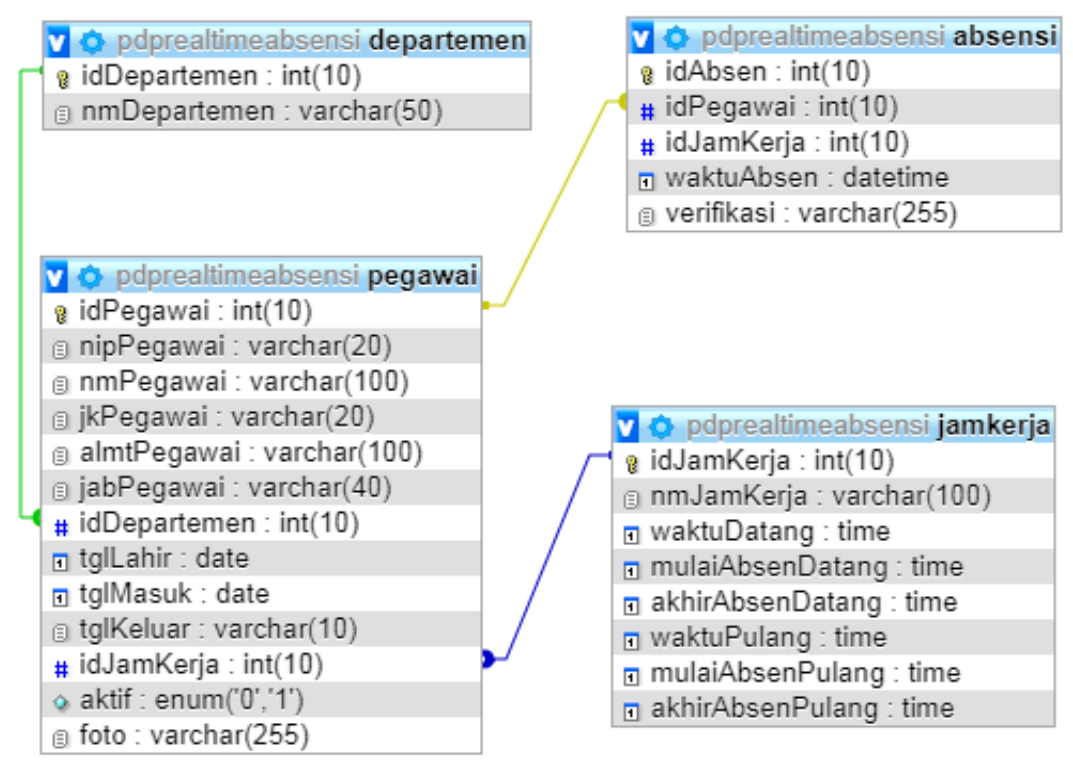

Gambar 3. Relasi Tabel 


\section{Hasil dan Pembahasan}

Hasil penelitian ini adalah sebuah arsitektur teknologi real-time monitoring kehadiran karyawan yang terintegrasi dengan mesin fingerprint yang siap diimplementasikan dengan biaya yang relatif murah dengan memanfaatkan software opensource. Tampilan aplikasi real-time monitoring ini dibedakan antara bagian kepegawaian dan bagian admin.

\subsection{Tampilan Aplikasi Real-time Monitoring Disisi Bagian Kepegawaian}

Pada bagian kepegawaian, aplikasi real-time monitoring kehadiran karyawan menampilkan karyawan yang datang di awal waktu dan menampilkan karyawan yang datang terakhir atau terlambat.

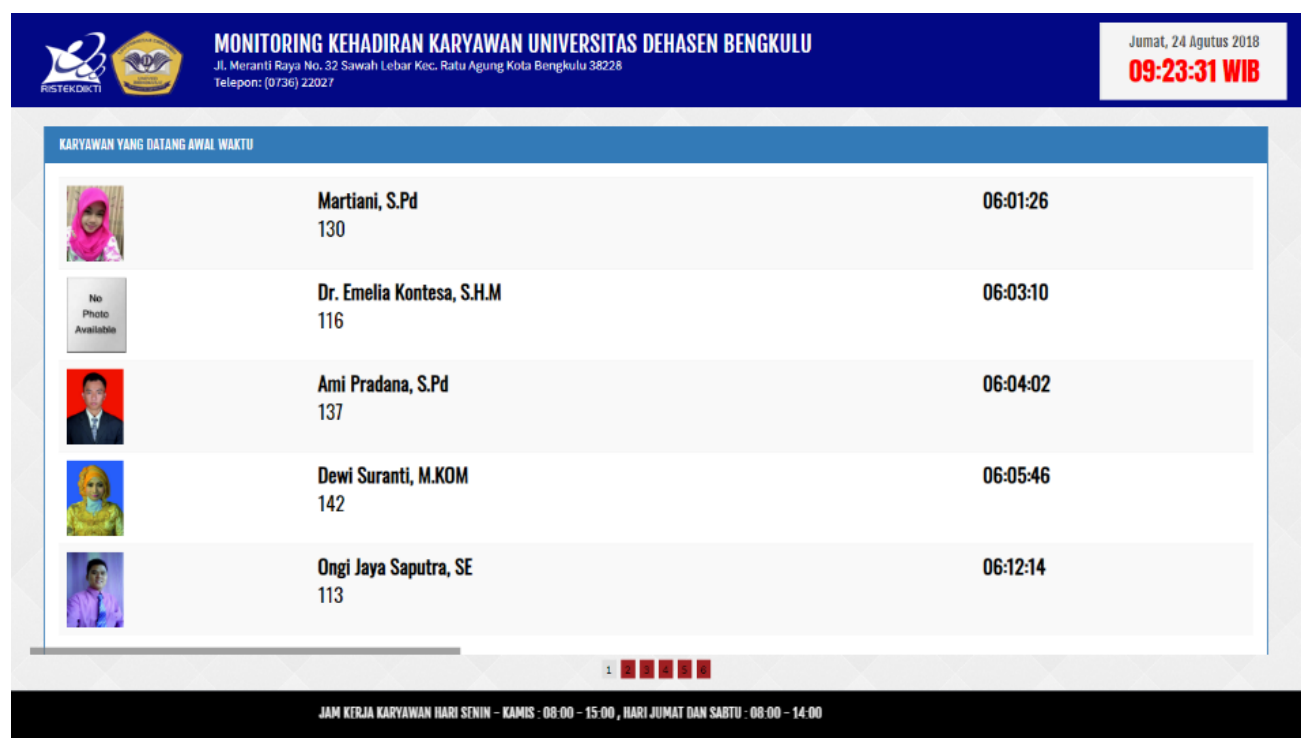

Gambar 4. Tampilan Karyawan yang Datang di Awal Waktu

Dari gambar di atas, terlihat 5 karyawan yang datang paling awal. Pada halaman ini juga ditampilkan waktu karyawan check-in pada mesin fingerprint. Sedangkan untuk tampilan karyawan yang datang terakhir terlihat pada gambar 5 di bawah ini.

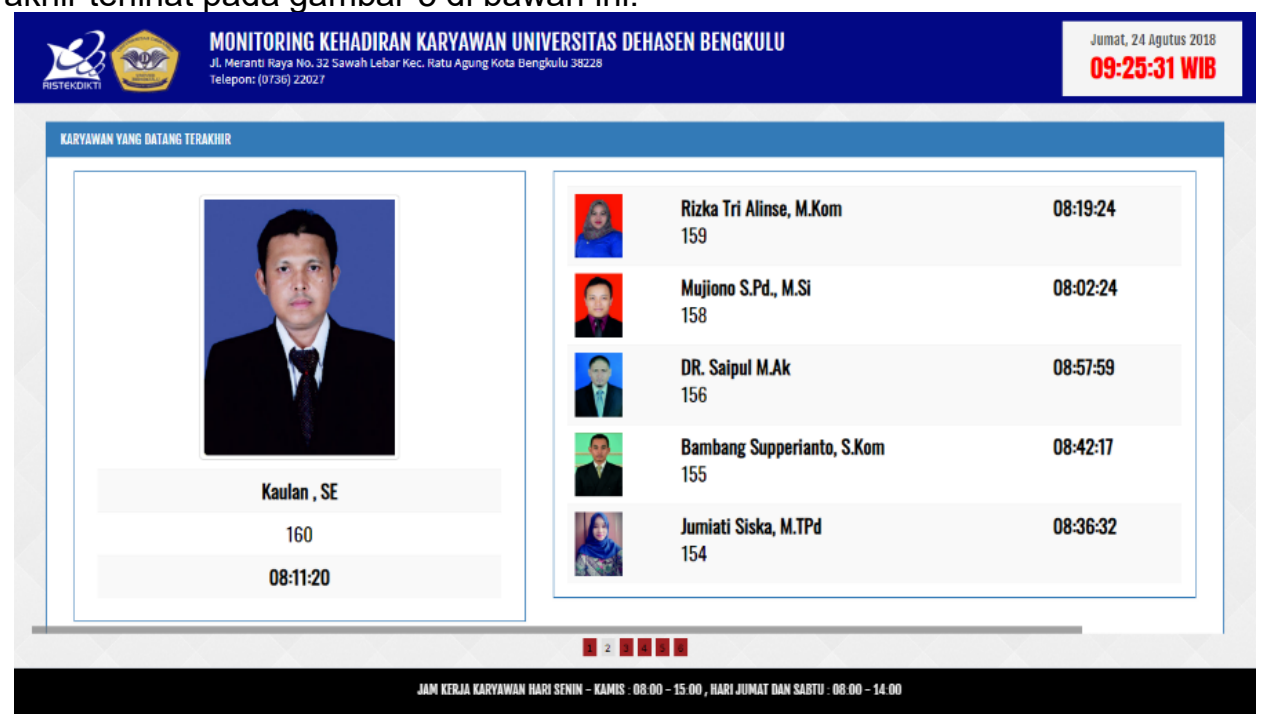

Gambar 5. Tampilan Karyawan yang Datang Terakhir

\subsection{Tampilan Aplikasi Real-time Monitoring Disisi Admin}

\subsubsection{Tampilan Login Aplikasi}

Untuk masuk ke halaman admin, diperlukan username dan password untuk login. Berikut ini tampilan halaman login. 


\section{LOGIN SISTEM ABSENSI}

Silahkan Login Pada Form dibawah ini

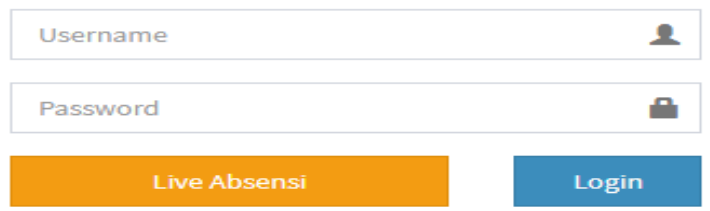

Gambar 6. Login Aplikasi

\subsubsection{Tampilan Dashboard Admin}

Setelah admin berhasil login maka akan ditampilkan dashboad admin seperti gambar berikut.

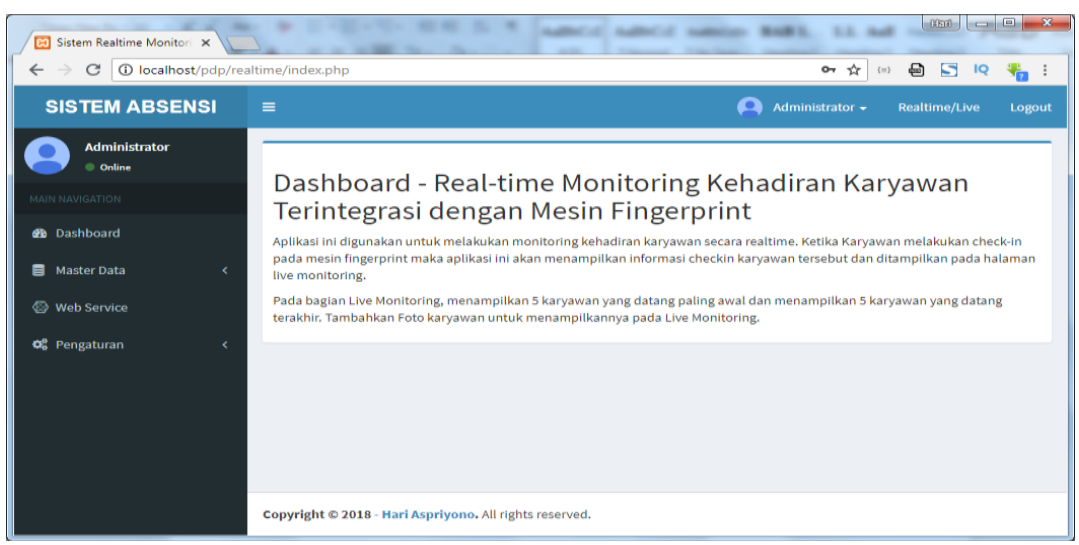

Gambar 7. Dashboard Admin

Pada bagian admin, terdapat beberapa menu diantaranya Master Data, Web Service dan Pengaturan. Menu Master Data digunakan untuk mengelola data karyawan, data jam kerja dan pengumuman. Menu webservice digunakan untuk berkomunikasi dengan mesin fingerprint seperti pengaturan koneksi ke mesin fingerprint, sinkronisasi waktu, dan restart mesin fingerprint. Sedangkan menu pengaturan digunakan untuk mengatur data admin dan mengatur teks yang akan ditampilkan pada running text di bagian layar real-time monitoring.

\subsubsection{Tampilan Master Data Karyawan}

Bagian penting yang dikelola oleh administrator adalah data karyawan. Berikut ini tampilan master data karyawan.

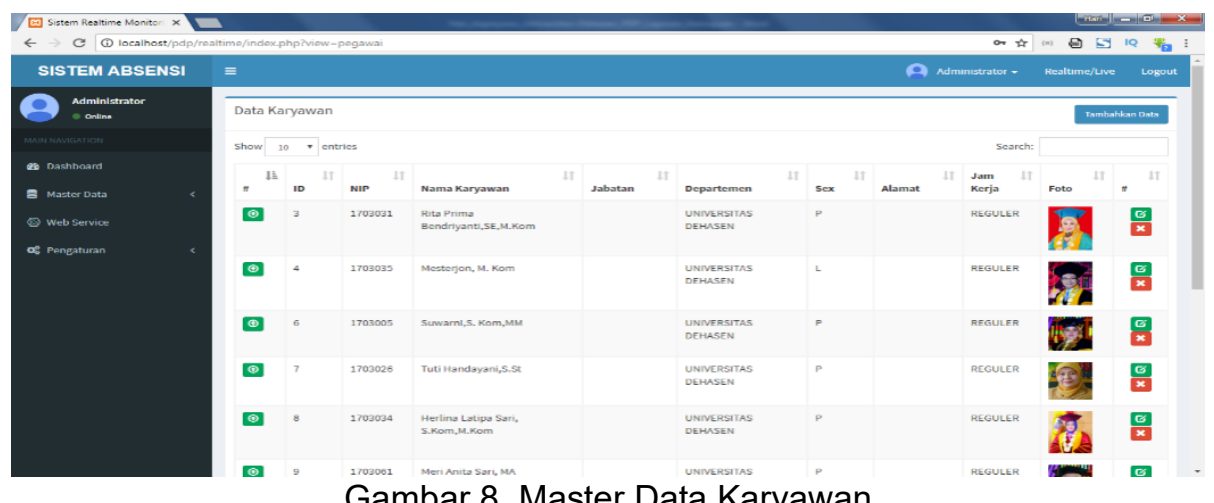


Pada menu master data karyawan, selain digunakan untuk input karyawan, edit karyawan dan hapus karyawan juga terdapat fasilitas untuk upload data karyawan ke mesin fingerprint.

\subsubsection{Tampilan Master Jam Kerja}

Master jam kerja digunakan oleh admin dalam menentukan jam kerja untuk karyawan.

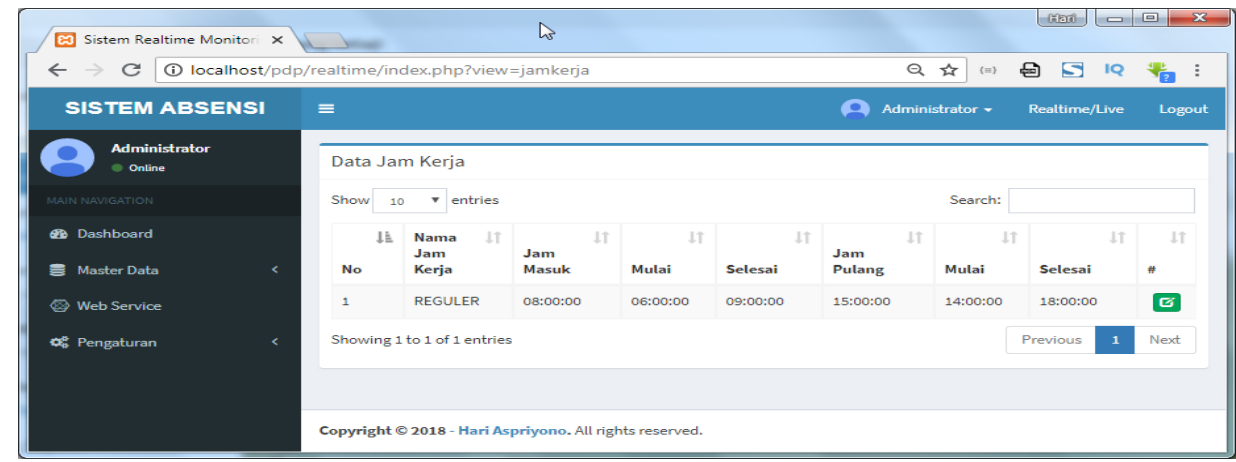

Gambar 9. Master Jam Kerja

Untuk melihat performa atau kemampuan sistem real-time monitoring kehadiran karyawan, apakah telah berjalan dengan baik sesuai dengan yang diharapkan atau belum, maka perlu dilakukan pengujian sistem. Pengujian sistem dilakukan menggunakan metode black box.

a. Pengujian Form Login

Tabel 1. Hasil Pengujian Form Login

\begin{tabular}{llll}
\hline \multicolumn{1}{c}{ Data Uji } & \multicolumn{1}{c}{ Hasil Yang diharapkan } & \multicolumn{1}{c}{ Output } & Kesimpulan \\
\hline $\begin{array}{l}\text { Usename dan password } \\
\text { diinput dengan data yang } \\
\text { salah }\end{array}$ & $\begin{array}{l}\text { Menampilkan informasi } \\
\text { kesalahan login }\end{array}$ & $\begin{array}{l}\text { Menampilkan } \\
\text { popup “Username dan } \\
\text { Password Tidak } \\
\text { Valid!” }\end{array}$ & $\begin{array}{l}\text { Hasil input } \\
\text { data invalid }\end{array}$ \\
\hline $\begin{array}{l}\text { Username dan password } \\
\text { diinput dengan data yang } \\
\text { benar }\end{array}$ & $\begin{array}{l}\text { Login berhasil dan } \\
\text { menampilkan Dashboard } \\
\text { Administrator }\end{array}$ & $\begin{array}{l}\text { Menampilkan } \\
\text { Dashboard }\end{array}$ & $\begin{array}{l}\text { Hasil input } \\
\text { data valid }\end{array}$ \\
\hline
\end{tabular}

b. Pengujian Upload Data Karyawan dari Aplikasi Ke Mesin Fingerprint

Tabel 2. Hasil Pengujian Upload Data ke Mesin Fingerprint

\begin{tabular}{|c|c|c|c|}
\hline Data Uji & Hasil yang diharapkan & Output & Kesimpulan \\
\hline $\begin{array}{l}\text { Admin mengklik } \\
\text { tombol upload data } \\
\text { pada data karyawan }\end{array}$ & $\begin{array}{l}\text { Layar mesin fingerprint } \\
\text { berkedip data karyawan } \\
\text { masuk ke mesin fingerprint }\end{array}$ & $\begin{array}{l}\text { Layar mesin fingerprint } \\
\text { berkedip data masuk ke } \\
\text { mesin fingerprint }\end{array}$ & Hasil tes valid \\
\hline
\end{tabular}

Selain pengujian black-box, juga dilakukan pengujian kecepatan sinkronisasi data presensi dari mesin fingerprint dengan aplikasi real-time monitoring kehadiran karyawan. Pengujian dilakukan dengan menghitung selisih waktu dari waktu karyawan check-in pada mesin fingerprint dengan waktu informasi kehadiran karyawan tersebut tampil di aplikasi. Kecepatan Sinkronisasi dipengaruhi dari jumlah data karyawan dan rekaman data presensi yang tersimpan pada mesin fingerprint. Pengujian ini dilakukan dengan data karyawan yang berjumlah 145 Karyawan. Hasil pengujian akan dikategorikan dalam 3 jenis yaitu:
a. Sangat Cepat $(0-3$ detik $)$
b. Cepat (4 - 10 detik)
c. Lambat (diatas 10 detik)

Tabel 3. Hasil Pengujian Sinkronisasi Data

\begin{tabular}{llcl}
\hline Jumlah Karyawan & \multicolumn{1}{c}{$\begin{array}{c}\text { Data Presensi } \\
\text { Tersimpan Dalam } \\
\text { Rentang Waktu }\end{array}$} & $\begin{array}{c}\text { Waktu Sinkronisasi } \\
\text { (Detik) }\end{array}$ & Kesimpulan \\
\hline 145 Orang & 1 Hari & 1 & Sangat Cepat \\
\hline 145 Orang & 2 Hari & 1 & Sangat Cepat \\
\hline 145 Orang & 3 Hari & 2 & Sangat Cepat \\
\hline 145 Orang & 1 Minggu & 4 & Cepat \\
\hline
\end{tabular}


ILKOM Jurnal Ilmiah Volume 10 Nomor 3 Desember 2018

\begin{tabular}{llll}
\hline 145 Orang & 1 Bulan & 8 & Cepat \\
\hline 145 Orang & 2 Bulan & 12 & Lambat \\
\hline 145 Orang & 3 Bulan & 18 & Lambat \\
\hline
\end{tabular}

\section{Kesimpulan dan Saran}

Aplikasi real-time monitoring kehadiran karyawan pada Universitas Dehasen Bengkulu berjalan baik dari sisi kemampuan validasi data autentikasi (login), sinkronsdxasi waktu dan proses upload data karyawan dari aplikasi ke mesin fingerprint. Waktu sinkronisasi data berjalan sangat cepat pada kondisi data yang tersimpan pada mesin fingerprint pada rentang waktu 1 hari - 3 hari, sedangkan untuk data yang tersimpan 1 minggu - 1 bulan sinkronisasi berjalan cepat dan data 2 bulan ke atas sinkronisasi berjalan lambat. Untuk menghindari selisih waktu pada pada mesin fingerprint dengan waktu yang tampil pada aplikasi, perlu dilakukan sinkronisasi waktu oleh admin dengan memastikan bahwa waktu pada aplikasi sudah benar.Perlu dilakukan backup data dari mesin fingerprint yang dilakukan secara berkala minimal sekali dalam 1 bulan untuk mengantisipasi kehilangan data yang kemungkinan terjadi.

\section{Daftar Pustaka}

[1] Y. Adhawiyah, N. Kumaladewi, and M. Caturutami, "Rancang Bangun Sistem Informasi Penilaian Kinerja Pegawai Menggunakan Metode Psycological Appraisal,” Stud. Inform. J. Sist. Inf., vol. 10, no. 2, pp. 119-126, 2017.

[2] L. B. Hasiolan, A. Fathoni, and D. Kota, "Pengaruh Mekanisme Finger Print, Prosedur Finger Print , Pencapaian Target Finger Print Terhadap Kedisiplinan Pegawai Di Sekretariat Dewan Perwakilan Rakyat Daerah," J. Manage., vol. 2, no. 2, 2016.

[3] David Naista, Bikin Framework PHP Sendiri Dengan Teknik OOP \& MVC. Yogyakarta: Lokomedia, 2016.

[4] B. Raharjo, Belajar Otodidak MySQL (Teknik Pembuatan dan Pengelolaan Database). Bandung: Informatika, 2015.

[5] C. F. A. Sari and L. Yulianto, "Perancangan Sistem Informasi Absensi Menggunakan Finger Print di Badan Perencanaan Pembangunan Daerah dan Penanaman Modal Kabupaten Pacitan," Semin. Ris. Unggulan Nas. Inform. dan Komput. FTI UNSA, vol. 2, no. 1, pp. 1-7, 2013. 